Article

\title{
Ground Level Ozone Formation Near a Traffic Intersection: Lisbon "Rotunda De Entrecampos" Case Study
}

\author{
Angelo Roldão Soares ${ }^{1}$, Duarte Neto ${ }^{2}$, Tiago Avelino ${ }^{2}$ and Carla Silva ${ }^{1, *(1)}$ \\ 1 Instituto Dom Luiz (IDL), Faculdade de Ciências, Universidade de Lisboa, Campo Grande, 1250-096 Lisboa, \\ Portugal; arsoares@fc.ul.pt \\ 2 MSc Energy and Environment, Faculdade de Ciências, Universidade de Lisboa, 1250-096 Lisboa, Portugal; \\ duarte.neto.92@gmail.com (D.N.); tiagofilipe_93@hotmail.com (T.A.) \\ * Correspondence: camsilva@fc.ul.pt
}

Received: 3 March 2020; Accepted: 24 March 2020; Published: 27 March 2020

\begin{abstract}
Ground-level ozone in cities is increasing mainly due to traffic exhaust aftertreatment devices, i.e., tailpipe catalytic converters. The chemical reaction of $\mathrm{O}_{3}$ formation indicates radiation and nitrogen oxides as main players. Thus, we investigate correlations between $\mathrm{O}_{3}$, global radiation, nitrogen oxides, temperature, and precipitation in several periods of the year (2017) near a traffic roundabout in Lisbon city (coordinates $38^{\circ} 44^{\prime} 55^{\prime \prime}$ lat, $-9^{\circ} 08^{\prime} 56^{\prime \prime}$ long). The weekend effect, school break versus school period, day and night, and seasonal effect were explored. Low-cost sensors (LCS) of $\mathrm{O}_{3}, \mathrm{NO}_{x}$, and temperature were tested to see if they can be used to get historical data on other cities and locations. The main innovation is the calibration of the sensor directly with real data (uncontrolled environment). Raw data were compared and led us to conclude that MQ-131 has a better performance than the MICS-4514 sensor. The results indicate that the diurnal cycle of ozone concentration has a mid-day peak around 1-2 pm and a lower nighttime concentration below $5 \mathrm{ppb}$ Weekends and school break period (251 days a year) have the highest values of Ozone, this is due to lower $\mathrm{NO}_{\mathrm{x}}$ emissions and thus lower levels of ozone destruction reaction ( $\mathrm{NO}_{\mathrm{x}}$-titration reaction). August is a hotspot month with a maximum concentration of $71 \mathrm{ppb}$.
\end{abstract}

Keywords: global radiation; nitrogen oxides; low-cost sensors; weekend effect; seasonal effect

\section{Introduction}

Lower tropospheric ozone is considered an important photo-oxidant produced from photochemical reactions in urban environments [1]. The formation of this pollutant has been increasing in cities mainly due to traffic exhaust aftertreatment devices, i.e., tailpipe catalytic converters. High concentrations of ozone $\left(\mathrm{O}_{3}\right)$ are of particular concern to public health and its effects are well documented [2,3]. It is also recognized as one of the most important greenhouse gases by the Intergovernmental Panel on Climate Change (IPPC) [4]. Despite knowing all this, understanding the full extent of ozone formation has proven difficult and hard to control. The chemical reaction of $\mathrm{O}_{3}$ formation indicates that radiation and nitrogen oxides are the main players. Furthermore, it is believed, that the main sources of ground ozone stem from the complex relationship between nitrogen oxides $\left(\mathrm{NO}_{\mathrm{x}}\right)$ and volatile organic compounds (VOCs). The increase of VOCs concentrations always leads to more $\mathrm{O}_{3}$ formation, however, increasing $\mathrm{NO}_{x}$ can lead to more or less $\mathrm{O}_{3}$, depending on the ratio between $\mathrm{NO}_{x}$ and VOCs. In other words, at low VOCs $/ \mathrm{NO}_{x}$ ratios, the main reaction is between $\mathrm{OH}$ and $\mathrm{NO}_{2}$, in which the radical is removed and the formation of $\mathrm{O}_{3}$ is delayed. At higher $\mathrm{VOC} / \mathrm{NO}_{\mathrm{x}}$ ratios, the $\mathrm{OH}$ radical reactions are favored increasing $\mathrm{O}_{3}$ formation [5]. These interactions of $\mathrm{VOCs}, \mathrm{NO}_{\mathrm{x}}, \mathrm{NO}$ and $\mathrm{NO}_{2}$, are now suspected 
to play a key role on a counter-intuitive phenomenon called the "weekend effect," in which ozone concentrations are higher during the weekend, a time where it would be expected that lower $\mathrm{NO}_{2}$ production would form less $\mathrm{O}_{3}$. Collaborative research studies have been conducted with a focus on what can be the possible cause of such phenomena. The California Air Resources Board (CARB) has identified six possible explanations for the weekend effect for ozone [6,7]. Out of these six, we highlight the three main most probable causes: (1) the reduction of $\mathrm{NO}_{\mathrm{x}}$ concentrations on weekends reduce the titration of ozone; (2) the change in the $\mathrm{NO}_{\mathrm{x}}$ emissions timing allow for more efficient ozone production; (3) lower soot in the air during the weekend lets more sunlight reach lower tropospheric regions.

Several studies have been conducted in this regard, attempting to pinpoint the reason why in certain cities or rural areas such effect occurs [8,9].

Another important component of this research is the fact that to measure and study these effects, we usually rely on costly equipment. These high-cost sensors have low spatial density, which can make it difficult to assess how ozone truly behaves in any given area. This limits not only the feasibility of the studies, but also the amount of data that we are capable of collecting on this subject. For this reason, we propose a low-cost alternative to make measurements and increase data quantity and availability anywhere in the world. In the last decades, sensor technology has been greatly improved, creating new markets with cheaper and smaller sensors referred to as low-cost sensors (LCS) [10]. Low-cost sensing is a field that is undergoing expansion as technology improves. There are good indications on the viability of using these sensors for air quality monitoring [11,12].

This research seeks to find ground-level $\mathrm{O}_{3}$ relations with climatic influences (global radiation, temperature, and precipitation) and $\mathrm{NO}_{\mathrm{x}}$ precursors near a city traffic roundabout. It also aims at proving the performance of LCS in real urban environments and how these could be used to spread measuring spots, increasing the historically available data. A metric to harmonize the quantification of the "weekend" effect is also proposed.

\section{Materials and Methods}

The research was conducted in two steps: firstly, a piece of in-house low-cost equipment was built and tested using the Entrecampos air quality system (AQS) as the reference; secondly, the hourly $\mathrm{O}_{3}, \mathrm{NO}, \mathrm{NO}_{2}$, and meteorological data were collected for the year 2017. All data is provided in the Supplementary Materials. The nearest meteorological station from IPMA, located $2 \mathrm{~km}$ away, was used to get corresponding data for temperature $\left(\mathrm{T}-{ }^{\circ} \mathrm{C}\right)$, precipitation $(\mathrm{P}-\mathrm{mm} / \mathrm{h})$, and global radiation $\left(\mathrm{GR}-\mathrm{W} / \mathrm{m}^{2}\right)$. The conversion between $\mathrm{ppb}$ and $\mu \mathrm{g} / \mathrm{m}^{3}$ is seen in Table 1.

Table 1. Conversion ppm to $\mu \mathrm{g} / \mathrm{m}^{3}$.

\begin{tabular}{ccc}
\hline Species & $\mathbf{p p b}$ & $\mu \mathrm{g} / \mathbf{m}^{\mathbf{3}}\left(@ \mathbf{2 0}{ }^{\circ} \mathbf{C} ; \mathbf{1 . 0 1 3} \mathbf{~ a t m}\right)$ \\
\hline $\mathrm{O}_{3}$ & 1 & 2.00 \\
$\mathrm{NO}_{2}$ & 1 & 1.91 \\
$\mathrm{NO}$ & 1 & 1.25 \\
\hline
\end{tabular}

The theory supporting ground level or tropospheric ozone formation is complex. Photochemical and chemical reactions drive many of the processes that occur in the atmosphere by day and by night. Ozone is a secondary pollutant formed in the ambient air, through a complex set of sunlight-initiated reactions $(\mathrm{h} v)$ of its precursors, which are emissions of $\mathrm{NO}_{\mathrm{x}}\left(\mathrm{NO}_{2}+\mathrm{NO}\right)$.

$\mathrm{NO}$ from internal combustion engine vehicles (ICEV) easily oxidates to $\mathrm{NO}_{2}$. The photolysis of $\mathrm{NO}_{2}$ (daytime) produces oxygen atoms that react very quickly with molecular oxygen and form $\mathrm{O}_{3}[13,14]$.

$$
\mathrm{NO}_{2}+\mathrm{h} v \rightarrow \mathrm{NO}+\mathrm{O}
$$




$$
\begin{gathered}
\mathrm{O}+\mathrm{O}_{2} \rightarrow \mathrm{O}_{3} \\
\mathrm{Or}, \mathrm{NO}_{2}+\mathrm{hv}+\mathrm{O}_{2} \rightarrow \mathrm{NO}+2 / 3 \mathrm{O}_{3}
\end{gathered}
$$

When there is a high level of $\mathrm{NO}$ in $\mathrm{NO}_{x}$ emissions, the following reactions take place (independent of radiation, for example during nighttime) that cause $\mathrm{O}_{3}$ destruction, ozone quenching or titration:

$$
\begin{gathered}
\mathrm{NO}+\mathrm{O}_{3} \rightarrow \mathrm{NO}_{2}+\mathrm{O}_{2} \\
\mathrm{NO}_{2}+\mathrm{OH} \rightarrow \mathrm{HNO}_{3}
\end{gathered}
$$

The "weekend effect" in urban areas has been reported in several locations, e.g., Arizona [15], California [16], Chile [5], Ecuador [17], Mexico City [18], Rio de Janeiro [19], São Paulo [9], India [20] Shanghai [21], Guangzhou [22], Europe [23], and Cairo [24].

The phenomenon could be a result of lower NO levels, limiting reactions Reaction (1), (2), or (3), thus increasing the $\mathrm{O}_{3}$ lower absolute values. Due to different traffic patterns, NO peaks when GR is higher could also explain a more effective photochemical Reaction (1).

Regarding diurnal variations, the night $\left(\mathrm{GR}=0 \mathrm{~W} / \mathrm{m}^{2}\right)$ period also favors these reactions, Reaction (4) and (5), thus lowering $\mathrm{O}_{3}$ nighttime values comparatively to daytime.

Usually, ozone hot season is in the summer, where higher concentrations are observed for the

\begin{tabular}{|c|c|c|c|}
\hline Minimum (ppb) & Maximum (ppb) & Local & Reference \\
\hline NA * & $>600$ & Los Angeles (70's), US & {$[8]$} \\
\hline $\mathrm{NA}^{*}$ & 62 & Barcelona & [25] \\
\hline NA * & 44 & Belgrade & [26] \\
\hline 16 & 75 & Arizona, US & [15] \\
\hline 10 & 157 & Rio de Janeiro, Brazil & [19] \\
\hline 5 & 130 & Mexico City, Mexico & [18] \\
\hline 5 & 80 & Santiago, Chile & [5] \\
\hline 30 & 150 & Cairo, Morocco & [24] \\
\hline 10 & 80 & Shanghai, China & [21] \\
\hline 10 & 70 & Guangzhou, China & [22] \\
\hline 5 & 83 & Pune, India & [20] \\
\hline
\end{tabular}
same altitude in the troposphere, i.e., up to $15 \mathrm{~km}$. Historical concentrations observed in urban areas were collected and summarized in Table 2.

Table 2. Observed tropospheric ozone concentrations in urban areas from the literature review.

\subsection{Low-cost Equipment}

A low-cost prototype was built and calibrated in-situ versus high-cost equipment to attest for its capabilities. Low-cost sensing is undergoing change and expansion giving good indications of a promising future in air quality fields. Table 2 indicates possible ozone ranges and therefore equipment specifications in terms of detection limits. The developed equipment consists of an Arduino Uno interfacing with the DHT22, MQ-131 (Winsen Electronics, Zhengzhou, China) and MICS-4514 (Neuchâtel-Switzerland SGX Sensortech) sensors. Air quality sensor specifications indicate adequacy to measure $10 \mathrm{ppb}-1 \mathrm{ppm}$ for $\mathrm{O}_{3}$ and $50 \mathrm{ppb}-10 \mathrm{ppm}$ for $\mathrm{NO}_{2}$. A real-time clock (RTC DS1307) was installed to make a direct correspondence with the time of the day and pollutant concentration. An SD Shield 3.0 was used to store the data, and a fan was added to maintain airflow and refrigerate the box. The total cost of the final equipment is $92 €$ and its schematics can be seen in Figure 1. 


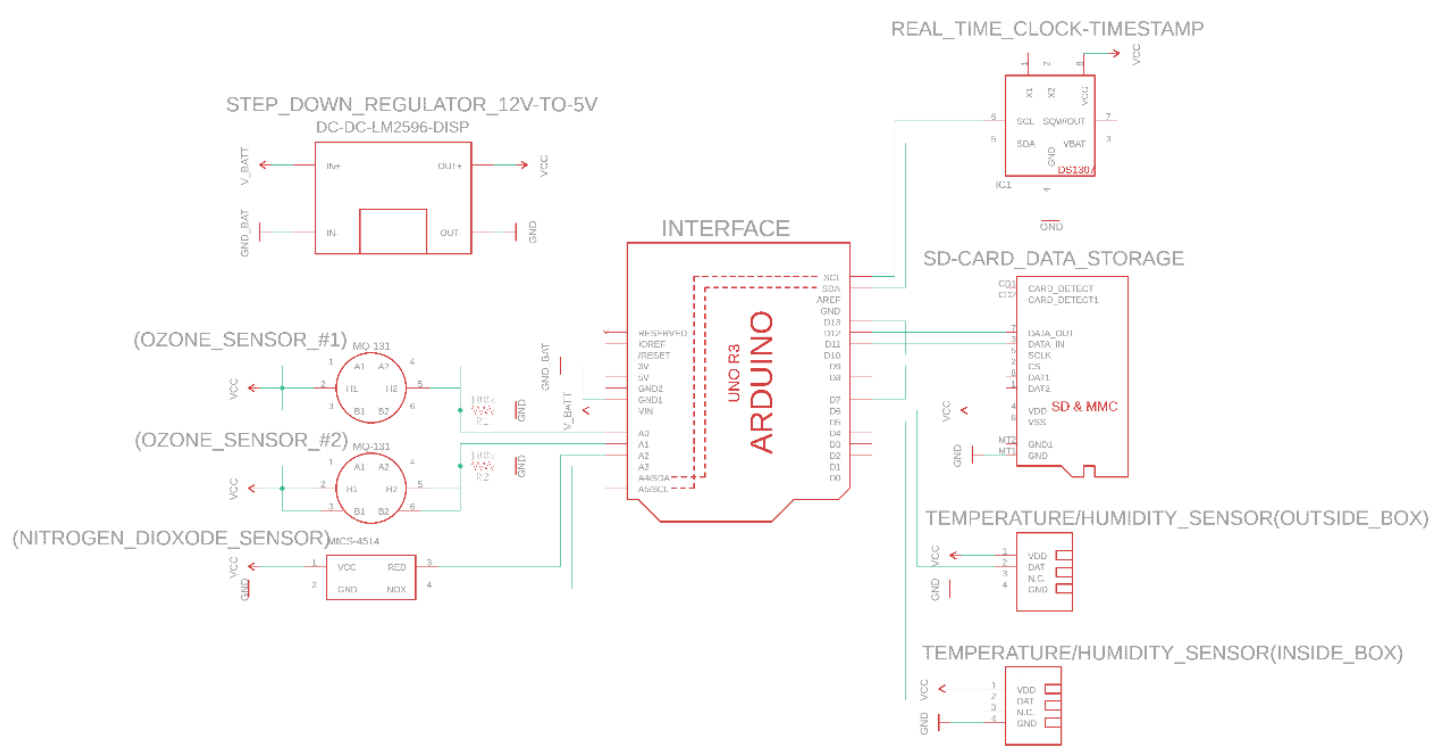

Figure 1. Schematics for the low-cost equipment-battery or AC/DC adapter powered (grid).

The low-cost equipment included a pair of MQ-131 sensors to evaluate manufacturing differences. The power consumption of the equipment is $644.5 \mathrm{~mA} \times 12 \mathrm{~V}=7.7 \mathrm{~W}$, which means an energy consumption of $7.7 \mathrm{Wh}$.

Previous research conducted with these types of sensors indicates a weak correlation with the calibration data [27], however, the sensor responses were modeled without external temperature and humidity corrections, as is the case with our experiments.

Peterson et al. 2017 [28] shows scatter plots of raw output voltage and $\mathrm{NO}_{2}$ concentration $\left(\mu \mathrm{g} / \mathrm{m}^{3}\right)$. Barcelo-Ordinas et al. 2019 [29] deals with the calibration of sensor networks in uncontrolled environments. Data faults (data reported by a sensor that is inconsistent with the phenomena of interest) can happen due to environmental noise, the precision of the equipment, and manufacturing defects.

According to Hagler et al. 2018 [30], the following parameters can have a justifiable influence on the results:

- elapsed time since manufacturing or deployment, if aging has been demonstrated to cause a change in sensor response;

- $\quad$ other gases for which cross-sensitivity has been established;

- temperature, for which measurement artifact has been established;

- relative humidity, for which measurement artifact has been established.

However, these are hardly reported in the literature. Moreover, sensors from the same family can have different behaviors that make correction functions even harder to derive and use. In this sense, the authors decided to measure in an uncontrolled environment and test the sensors directly, with real measured concentration through voltage (raw data).

\subsection{Measurement Campain}

The campaign was intended as a test of the LCS in an uncontrolled environment. The low-cost equipment was mounted on the rooftop of the Entrecampos AQS (coordinates $38^{\circ} 44^{\prime} 55^{\prime \prime}$ lat, $-9^{\circ} 08^{\prime} 56^{\prime \prime}$ long), near the air intake system for the high-cost sensors as seen in Figure 2. For ten days, in august, values were registered every $15 \mathrm{~min}$, adding to a total of 864 values for $\mathrm{O}_{3}$ and other 864 values for $\mathrm{NO}_{2}$. The $\mathrm{T}$ and $\mathrm{RH}$, inside and outside the device enclosure, were monitored to observe differences within. The outdoor sensor was also used to crosscheck outdoor conditions with the nearest meteorological station, $2 \mathrm{~km}$ apart ( $38^{\circ} 45^{\prime} 58^{\prime \prime}$ latitude, $-9^{\circ} 7^{\prime} 39^{\prime \prime}$ longitude). The equipment consumed $1.67 \mathrm{kWh}$ and was powered by one of the AQMS outlets (grid-connected). The maximum and minimum outdoor 
temperature and humidity were registered to compare with the conditions inside the equipment enclosure. The ranges observed for $\mathrm{O}_{3}, 1-55 \mathrm{ppb}$, are mostly within the limits of detection, but for $\mathrm{NO}_{2}, 1-67 \mathrm{ppb}$, these are mostly outside of the detection limit. For other periods of the year, it could be different, as the maximum values of $\mathrm{O}_{3}$ are detected for less $\mathrm{NO}_{\mathrm{x}}$ and the minimum $\mathrm{O}_{3}$ for maximum $\mathrm{NO}_{\mathrm{x}}$. In Table 3 we can see all minimum and maximum values registered during the campaign period.
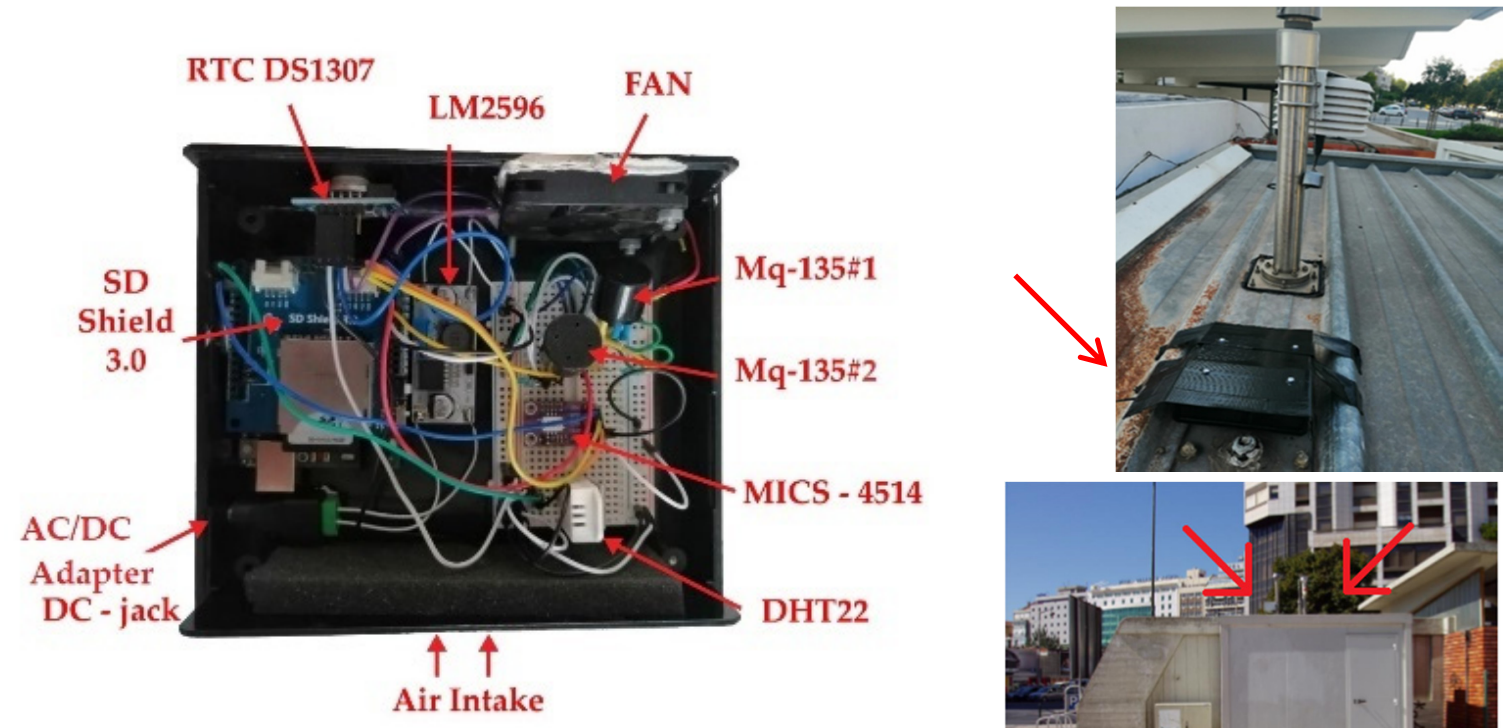

(a)

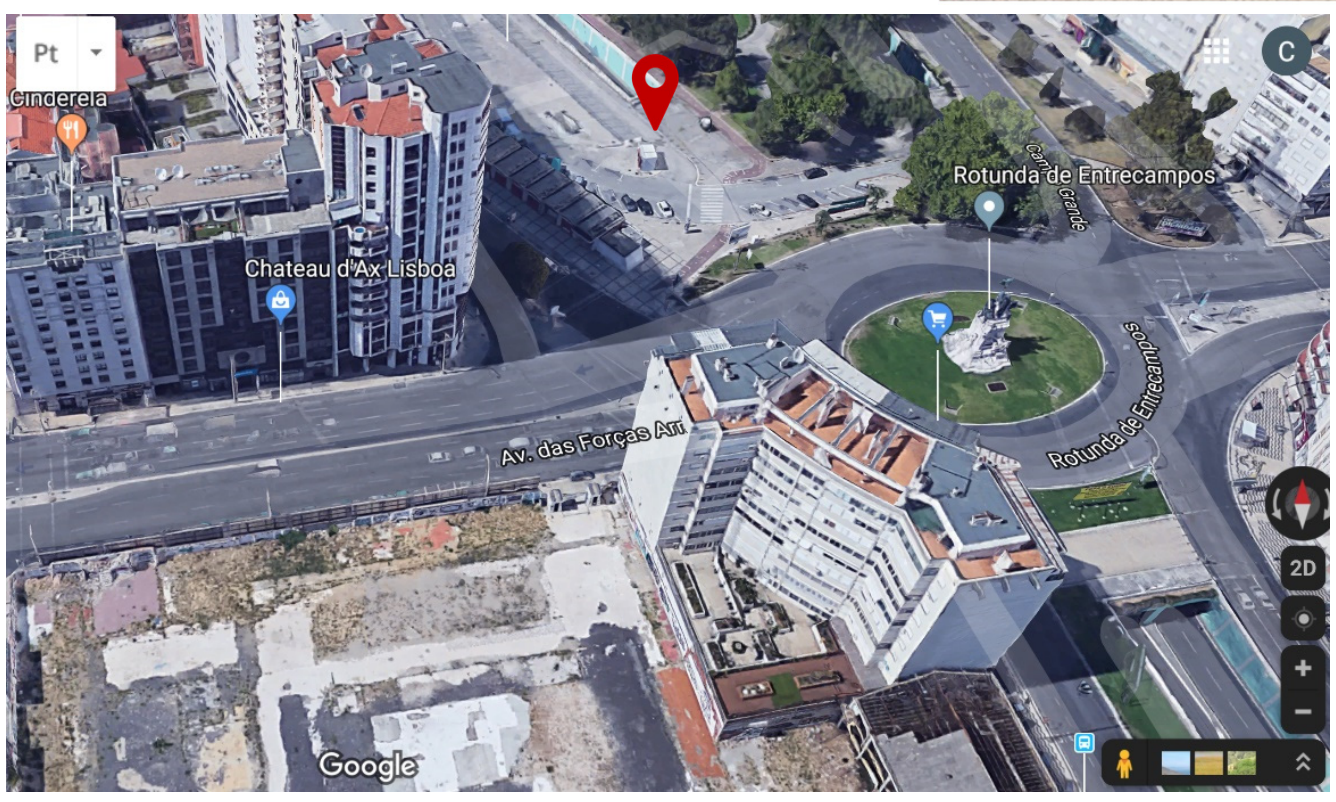

(b)

Figure 2. (a): Image of the prototype and subsequent mounting location on top of a reference air quality system (AQS); (b): Overview of the AQS location near the "Rotunda de Entrecampos". 
Table 3. Maximum and minimum values during the campaign, near the roundabout "Rotunda de Entrecampos", school break period, weekends (shadowed).

\begin{tabular}{|c|c|c|c|c|c|c|c|c|c|c|}
\hline \multirow{2}{*}{$\frac{\text { Day }}{\mathrm{T}}$} & \multicolumn{2}{|c|}{$\# 1$} & \multicolumn{2}{|c|}{$\# 2$} & \multicolumn{2}{|c|}{ \#3 } & \multicolumn{2}{|c|}{$\# 4$} & \multicolumn{2}{|c|}{ \#5 } \\
\hline & $24^{\circ} \mathrm{C} @ 12 \mathrm{~h}$ & $18^{\circ} \mathrm{C} @ 1 \mathrm{~h}$ & $30^{\circ} \mathrm{C} @ 14 \mathrm{~h}$ & $17^{\circ} \mathrm{C} @ 3 \mathrm{~h}$ & $33^{\circ} \mathrm{C} @ 14 \mathrm{~h} 30$ & $18^{\circ} \mathrm{C} @ 1 \mathrm{~h} 30$ & $29^{\circ} \mathrm{C} @ 13 \mathrm{~h}$ & $17^{\circ} \mathrm{C} @ 1 \mathrm{~h}$ & $28^{\circ} \mathrm{C} @ 13 \mathrm{~h}$ & $17^{\circ} \mathrm{C} @ 3 \mathrm{~h}$ \\
\hline RH & $60.9 \% @ 15 h$ & 93.9\%@1h30 & 27.1\%@14h & 88.1\%@3h & 27.6\%@14h & $88.1 \% @ 23 h 30$ & 27.1\%@14h & $93.9 \% @ 1 \mathrm{~h} 30$ & $44.8 \% @ 12 \mathrm{~h} 30$ & 93.8\%@3h \\
\hline $\mathrm{O}_{3}\left(\mu \mathrm{g} / \mathrm{m}^{3}\right)$ & $73 @ 15 h$ & 35 @6h30 & $80 @ 15$ h30 & $28 @ 6 h 15$ & 73 @13h30 & $18 @ 7 h$ & $79 @ 15 \mathrm{~h} 30$ & 3 @6h30 & $74 @ 13 h$ & $40 @ 20 \mathrm{~h} 45$ \\
\hline $\mathrm{O}_{3}(\mathrm{ppb})$ & 36.5 & 17.5 & 20 & 14 & 36.5 & 9 & 39.5 & 1.5 & 37 & \\
\hline $\mathrm{NO}_{2}\left(\mu \mathrm{g} / \mathrm{m}^{3}\right)$ & $35 @ 7 h 15$ & 4 @2h15 & $43.8 @ 12 \mathrm{~h} 15$ & $4.4 @ 4 h 15$ & 72.5@14h30 & $3.3 @ 3 h 15$ & $3 @ 6 h$ & $89.7 @ 14 \mathrm{~h} 30$ & $33.8 @ 9 h 15$ & $6.3 @ 3 h 15$ \\
\hline $\mathrm{NO}_{2}(\mathrm{ppb})$ & 18.3 & 2.1 & 22.9 & 2.3 & 38 & 1.7 & 1.6 & 47 & 17.7 & 3.3 \\
\hline Day & \multicolumn{2}{|c|}{$\# 6$} & \multicolumn{2}{|c|}{ \#7 } & \multicolumn{2}{|c|}{$\# 8$} & \multicolumn{2}{|c|}{$\# 9$} & \multicolumn{2}{|c|}{$\# 10$} \\
\hline $\mathrm{T}$ & $29^{\circ} \mathrm{C} @ 12 \mathrm{~h} 30$ & $17^{\circ} \mathrm{C} @ 6 \mathrm{~h} 30$ & $33^{\circ} \mathrm{C} @ 15 \mathrm{~h}$ & $17^{\circ} \mathrm{C} @ 2 \mathrm{~h}$ & $34{ }^{\circ} \mathrm{C} @ 13 \mathrm{~h}$ & $19^{\circ} \mathrm{C} @ 6 \mathrm{~h}$ & $34^{\circ} \mathrm{C} @ 12 \mathrm{~h}$ & $18^{\circ} \mathrm{C} @ 23 \mathrm{~h}$ & $34{ }^{\circ} \mathrm{C} @ 15 \mathrm{~h} 30$ & $17^{\circ} \mathrm{C} @ 6 \mathrm{~h}$ \\
\hline $\mathrm{RH}$ & 37.4\% @12h30 & 88.1\%@3h30 & 22.6\%@16h & $88 \% @ 2 h$ & $24.4 \% @ 16 \mathrm{~h}$ & $64.1 \% @ 5 \mathrm{~h} 30$ & $24.7 \% @ 12 \mathrm{~h}$ & 88.1\%@23h & 18.8\%@15h30 & 82.6\%@1h \\
\hline $\mathrm{O}_{3}\left(\mu \mathrm{g} / \mathrm{m}^{3}\right)$ & $73 @ 13 h 15$ & 40 @20h45 & $62 @ 17 \mathrm{~h} 45$ & 2 @6h15 & $84 @ 21 \mathrm{~h} 15$ & $2 @ 4 \mathrm{~h} 45$ & $109 @ 12 \mathrm{~h} 45$ & $2 @ 5 \mathrm{~h}$ & 100 @13h30 & $15 @ 7 h$ \\
\hline $\mathrm{O}_{3}(\mathrm{ppb})$ & 36.5 & 20 & 31 & 1 & 42 & 1 & 54.5 & 1 & 50 & \\
\hline $\mathrm{NO}_{2}\left(\mu \mathrm{g} / \mathrm{m}^{3}\right)$ & $33.8 @ 21 h$ & $6.3 @ 3 h 15$ & $118.5 @ 17 \mathrm{~h}$ & $5.4 @ 14 h$ & $119.7 @ 8 \mathrm{~h} 30$ & $20.821 \mathrm{~h} 15$ & $107.3 @ 7 \mathrm{~h}$ & $9.6 @ 0 \mathrm{~h}$ & $127.9 @ 17 \mathrm{~h}$ & $6.3 @ 1 \mathrm{~h}$ \\
\hline $\mathrm{NO}_{2}(\mathrm{ppb})$ & 17.7 & 3.3 & 62 & 2.8 & 62.7 & 10.9 & 56.2 & 5 & 67 & 3.3 \\
\hline
\end{tabular}




\subsection{AQS and Meteorological Data}

AQS data for $2017\left(38^{\circ} 44^{\prime} 55^{\prime \prime}\right.$ latitude, $-9^{\circ} 08^{\prime} 56^{\prime \prime}$ longitude) was obtained from the environmental agency web site and can be obtained in the downloads section [31]. A total of 8760 hourly data for $\mathrm{O}_{3}$, $\mathrm{NO}$, and $\mathrm{NO}_{2}$ were analyzed.

IPMA automatic station data, $2 \mathrm{~km}$ apart, was used to get the meteorological information $\left(38^{\circ} 45^{\prime} 58^{\prime \prime}\right.$ latitude, $-9^{\circ} 7^{\prime} 39^{\prime \prime}$ longitude) for the same year and time intervals, which gives a total of 8760 values for GR, T, and P. The total amount of data is 7 parameters $\times 8760=61,320$ datapoints (annexed in Supplementary Materials).

\section{Results}

\subsection{Measurement Field Campaign}

The main goal of the campaign was to test LCS in an uncontrolled environment. A pair of sensors was tested (two MQ-131), one new and the other already in use for 3 months, in the same location under the same conditions to assess drift and other factors. The developed prototype is intended to be used worldwide. To compare the sensor performance, regarding the air quality standards worldwide, it is important to know the time averages used in the standards. World Health Organization (WHO), US National Ambient Air Quality Standards (NAAQS), Europe, Egypt, India, and China have standards that may differ and are presented in Table 4.

Table 4. Reference Standards and Guidelines for Ambient $\mathrm{O}_{3}$ and $\mathrm{NO}_{2}$ Concentrations.

\begin{tabular}{|c|c|c|c|c|}
\hline Institute & Species & Time Average & Limit & Limit ppb (Table 2) \\
\hline $\mathrm{WHO}$ & \multirow{5}{*}{$\mathrm{O}_{3}$} & $8 \mathrm{~h}$ & $100 \mu \mathrm{g} / \mathrm{m}^{3}$ & 50 \\
\hline \multirow{2}{*}{ NAAQS } & & $8 \mathrm{~h}$ & $75 \mathrm{ppb}$ & 75 \\
\hline & & $1 \mathrm{~h}$ & $120 \mathrm{ppb}$ & 120 \\
\hline Europe & & $8 \mathrm{~h}$ & $120 \mu \mathrm{g} / \mathrm{m}^{3}$ & 60 \\
\hline \multirow[t]{2}{*}{ Egypt } & & $1 \mathrm{~h}$ & $200 \mu \mathrm{g} / \mathrm{m}^{3}$ & 100 \\
\hline & \multirow{8}{*}{$\mathrm{NO}_{2}$} & $8 \mathrm{~h}$ & $120 \mu \mathrm{g} / \mathrm{m}^{3}$ & 60 \\
\hline \multirow[t]{2}{*}{ India } & & $1 \mathrm{~h}$ & $180 \mu \mathrm{g} / \mathrm{m}^{3}$ & 90 \\
\hline & & $8 \mathrm{~h}$ & $100 \mu \mathrm{g} / \mathrm{m}^{3}$ & 50 \\
\hline \multirow[t]{2}{*}{ China } & & $1 \mathrm{~h}$ & $160 \mu \mathrm{g} / \mathrm{m}^{3}$ & 80 \\
\hline & & $8 \mathrm{~h}$ & $100 \mu \mathrm{g} / \mathrm{m}^{3}$ & 50 \\
\hline WHO & & $1 \mathrm{~h}$ & $200 \mu \mathrm{g} / \mathrm{m}^{3}$ & 105 \\
\hline \multirow[t]{2}{*}{ NAAQS } & & year & $53 \mathrm{ppb}$ & 53 \\
\hline & & $1 \mathrm{~h}$ & $100 \mathrm{ppb}$ & 100 \\
\hline \multirow[t]{2}{*}{ Europe } & & $1 \mathrm{~h}$ & $200 \mu \mathrm{g} / \mathrm{m}^{3}$ & 105 \\
\hline & & year & $40 \mu \mathrm{g} / \mathrm{m}^{3}$ & 21 \\
\hline \multirow[t]{2}{*}{ Egypt } & & $1 \mathrm{~h}$ & $400 \mu \mathrm{g} / \mathrm{m}^{3}$ & 209 \\
\hline & & $24 \mathrm{~h}$ & $150 \mu \mathrm{g} / \mathrm{m}^{3}$ & 79 \\
\hline \multirow[t]{2}{*}{ India } & & $24 \mathrm{~h}$ & $80 \mu \mathrm{g} / \mathrm{m}^{3}$ & 42 \\
\hline & & annual & $40 \mu \mathrm{g} / \mathrm{m}^{3}$ & 21 \\
\hline \multirow[t]{3}{*}{ China } & & $1 \mathrm{~h}$ & $200 \mu \mathrm{g} / \mathrm{m}^{3}$ & 105 \\
\hline & & $24 \mathrm{~h}$ & $80 \mu \mathrm{g} / \mathrm{m}^{3}$ & 42 \\
\hline & & year & $40 \mu \mathrm{g} / \mathrm{m}^{3}$ & 21 \\
\hline
\end{tabular}

Despite the variability across countries, the developed prototype should be able to cover the overall spectrum of possibilities. Moreover, even if not adequate for instantaneous reading, the time averages to calculate the limits ( $1 \mathrm{~h}, 8 \mathrm{~h}$, and $24 \mathrm{~h}$ ) should be tested to see if the equipment follows the trend of real data. This way we can test the usability of the prototype as an AQS. The placement of the temperature and relative humidity sensors were intended to capture both the temperature inside and outside the equipment. We do this to gauge the differences in temperature and workout if correction 
factors should be implemented in the Arduino code, or, if changes should be made to the prototype itself to avoid temperature disparities. These temperature differences values can be seen in Figure 3 .

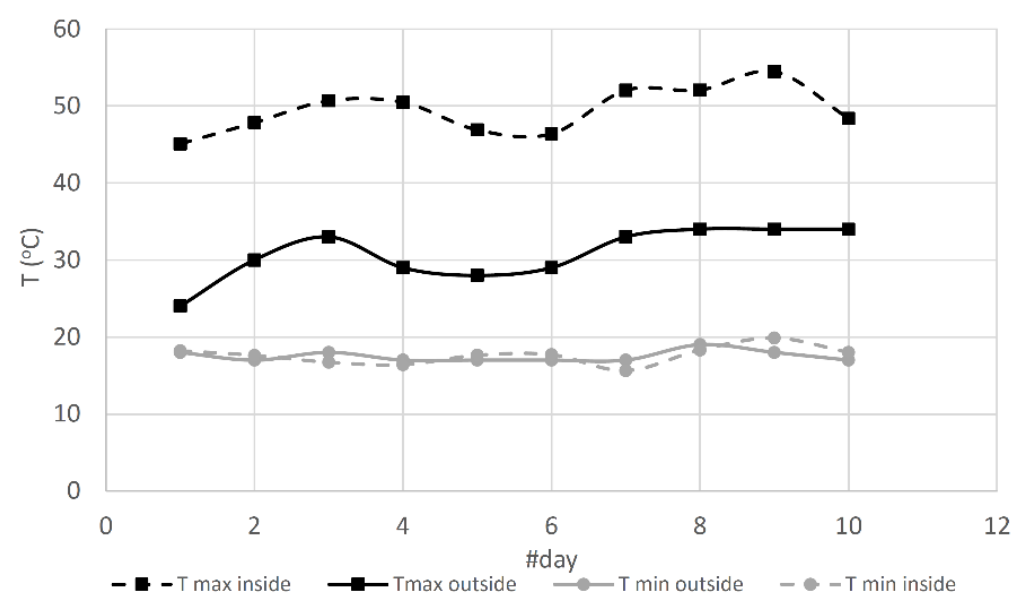

Figure 3. Temperature distribution in the prototype (outside and inside).

The temperature distribution (Figure 3) shows a systematic difference of $10-20^{\circ} \mathrm{C}$ higher inside the equipment enclosure when compared to outdoor ambient temperature. From this, we retain that the first step should be the sheltering of the equipment from the sun to prevent overheating. RH is similar inside and outside (Figure 4). The application of correction algorithms should also be considered to further decrease any potential variability in measurements.

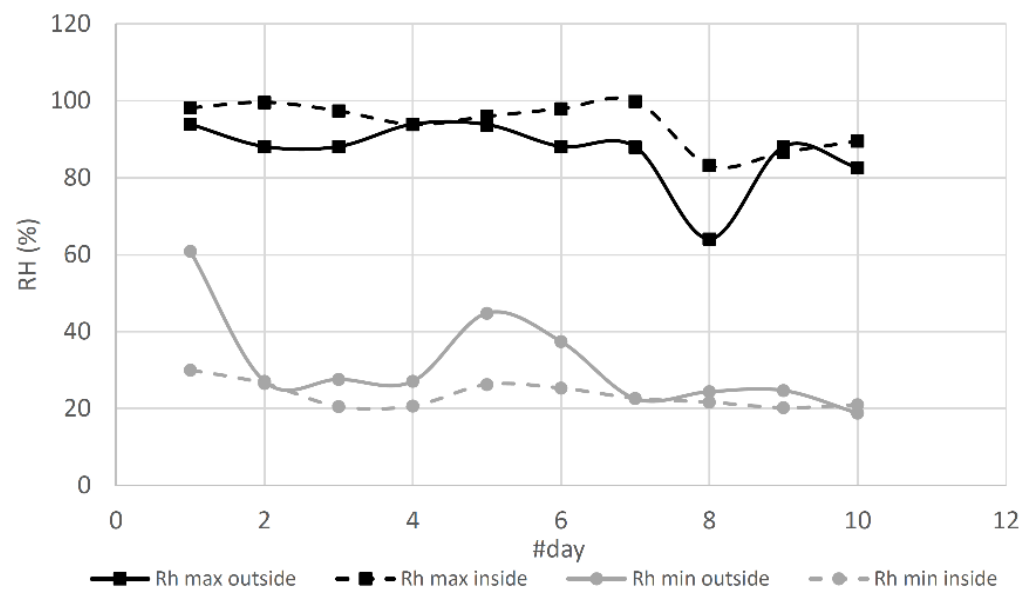

Figure 4. Relative humidity distribution in the prototype (outside and inside).

To make assessments on the possibility of these LCS to be used not only for instantaneous measurements but also to be compared with norms and directives, considerations were made based on hourly, $8 \mathrm{~h}$, and daily averages of measurements taken. Some data was unable to be correlated because $44 \%$ of the Entrecampos AQS data falls outside of the $\mathrm{NO}_{2} \mathrm{LCS}$ measurement range in the summer period in analysis. It would be interesting to see, in an extended campaign, how these values relate to the winter season.

We found tests of two identical sensors (MICS-4514) for a field campaign conducted in a semi-rural area during $3024 \mathrm{~h}, 20$ weeks [27]. The study claims that a multivariate linear regression model (MLR) was the best fit for the calibration $\left(R^{2}=0.525\right.$ or 0.786$)$, but performs poorly at the validation $\left(R^{2}=0.01\right.$ or 0.016$)$. The linear regression model (LR) performed worse at calibration $\left(R^{2}=0.168\right.$ or 0.269$)$, but slightly better at validation $\left(R^{2}=0.016\right.$ or 0.203$)$. This study also shows the inconsistency between sensors of the same brand and model; however, it states that values stay within the same range. 
O3_3E1F Citytech sensor (Life Safety Germany GmbH, City Technology, Bonn, Germany), was the sensor that performed better in calibration and validation, in the semi-rural area, achieving strong calibration values using MLR $\left(R^{2}=0.852\right.$ or 0.945$)$ and good validation $\left(R^{2}=0.584\right.$ or 0.824$)$.

In our 10-day field study, Figure 4 shows $\mathrm{O}_{3}$ instantaneous monitored data of a random day, taken every $15 \mathrm{~min}$. We also see these measurements averaged over 1, 8 and $24 \mathrm{~h}$ in Figure 5. As we can observe in Figure 5a, sensor \#1, the new sensor identical to sensor \#2, exhibited a substantial difference in behavior. This can be due to a manufacturing defect. Sensor \#2, despite being in use for at least 3 months prior to this field campaign, exhibited a more coherent behavior. Therefore, we used sensor \#2 for further analysis.

Without any $\mathrm{T}$ and $\mathrm{RH}$ correction, sensor \#2 voltage is highly scattered towards a linear relation with real $\mathrm{O}_{3}$, especially with 1 -h averages (Figure $5 \mathrm{~d}$ ). The linear model to correlate voltage and $\mathrm{O}_{3}$ values is not adequate. Moreover, using the linearity between voltage and $\mathrm{O}_{3}$, about $40 \%$ of the data would not comply with the Data Quality Objective (DQOs) of the European Air Quality Directive for indicative methods (between $25 \%$ and $30 \%$ of uncertainty for $\mathrm{O}_{3}$ and $\mathrm{NO}_{2}$ ). For the $8 \mathrm{~h}$ average, $37 \%$ of the data is outside DQO. For the daily average, $20 \%$ of the data is outside DQO.

Going to more elaborated calibration models could improve the performance to comply with $\mathrm{DQO}$ at the calibration, but not necessarily mean that the sensors will perform within DQO at other real conditions. Furthermore, it could mean that we are including parameters of questionable integrity [30] such as wind speed or direction, atmospheric mixing height, and location relative to sources.

\subsection{Seasonal Effect, Day and Night, School Period}

Another part of this study included the historical data of a real AQS near a traffic roundabout and the observation of correlations among measured variables: $\mathrm{O}_{3}, \mathrm{NO}_{2}, \mathrm{~T}, \mathrm{RH}$, pluviosity, GR, and to get minimum and maximum values for LCS to see if they can measure within the DQO. All the historical data from 2017 was used for yearly analysis. The data for each hour of the day was averaged for the considered period to get its trends, so each pattern represents an average day in the respective period (Figure 6).

The provided data for 2017 revealed a minimum $\mathrm{O}_{3}$ concentration of $1 \mathrm{ppb}$ (nighttime, weekday, school period) and a maximum of $71 \mathrm{ppb}$ in August, a Sunday at noon (daytime, weekend, school break period). Winter season (December, January, February) has the lowest averages and summer (June, July, August) the highest.

Regarding $\mathrm{NO}_{2}$ concentrations, for the same year, a peak of $116 \mathrm{ppb}$ occurred in winter at nighttime. A minimum of 1 ppb was observed in August also at nighttime. The average seasonal ozone peak seems to occur earlier in summer than in winter, in other words, the peak in winter occurs around $2 \mathrm{pm}$ and in summer around $1 \mathrm{pm}$. $\mathrm{NO}_{2}$ behavior is opposed to $\mathrm{O}_{3}$, the higher values are on weekdays during the school period, caused by the higher traffic activity due to school commuting.

As expected, GR is within the maximum summer and minimum winter values, which coincides with average temperature maximums and minimums (Figure 7). Precipitation was rather random, nevertheless, summer and autumn showed the lowest levels in $\mathrm{mm} / \mathrm{h}$ (Figure 7). 

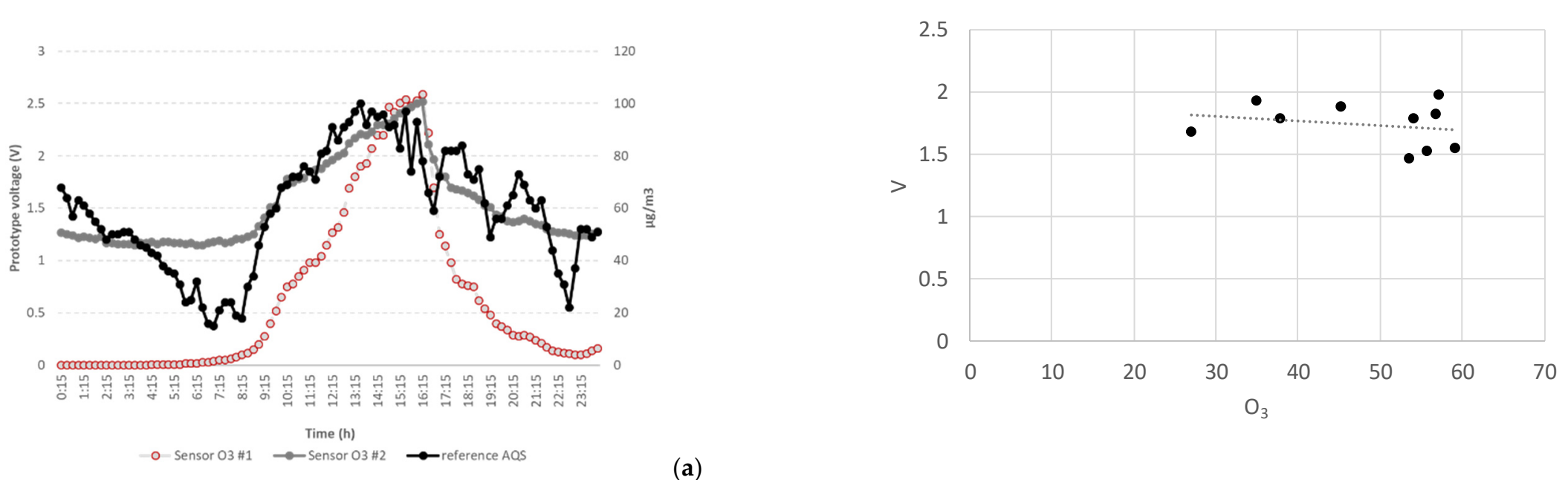

(a)
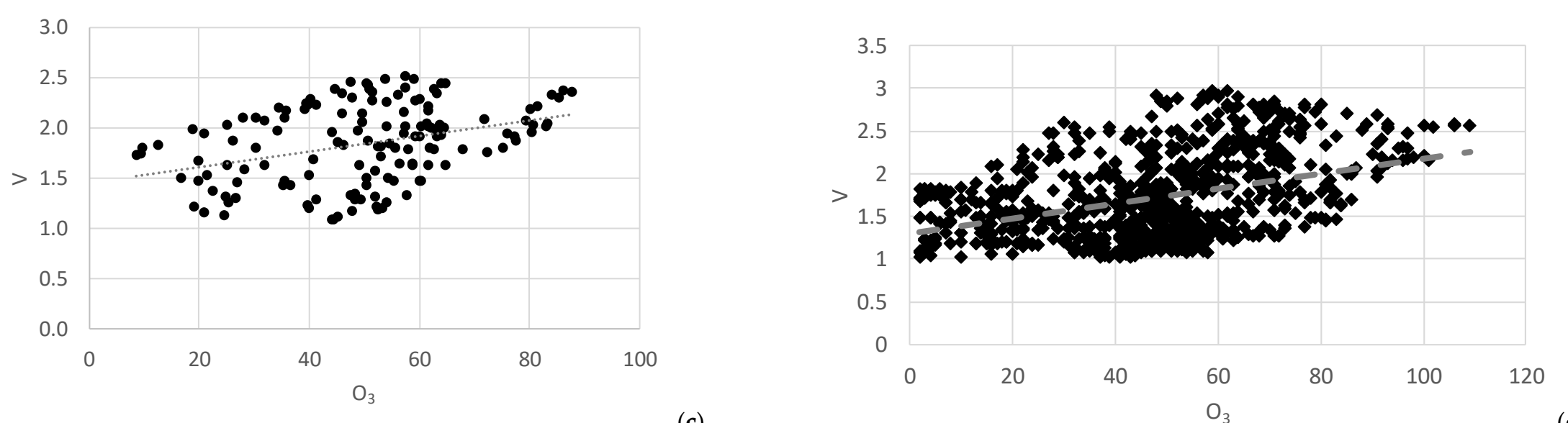

(c)

(d)

Figure 5. (a): $\mathrm{O}_{3}$ monitored data for a random day $(0.25 \mathrm{~h})$; $(\mathbf{b}): 24 \mathrm{~h}$ averages; $(\mathbf{c}): 8 \mathrm{~h}$ averages; $(\mathbf{d}): 1 \mathrm{~h}$ averages. 

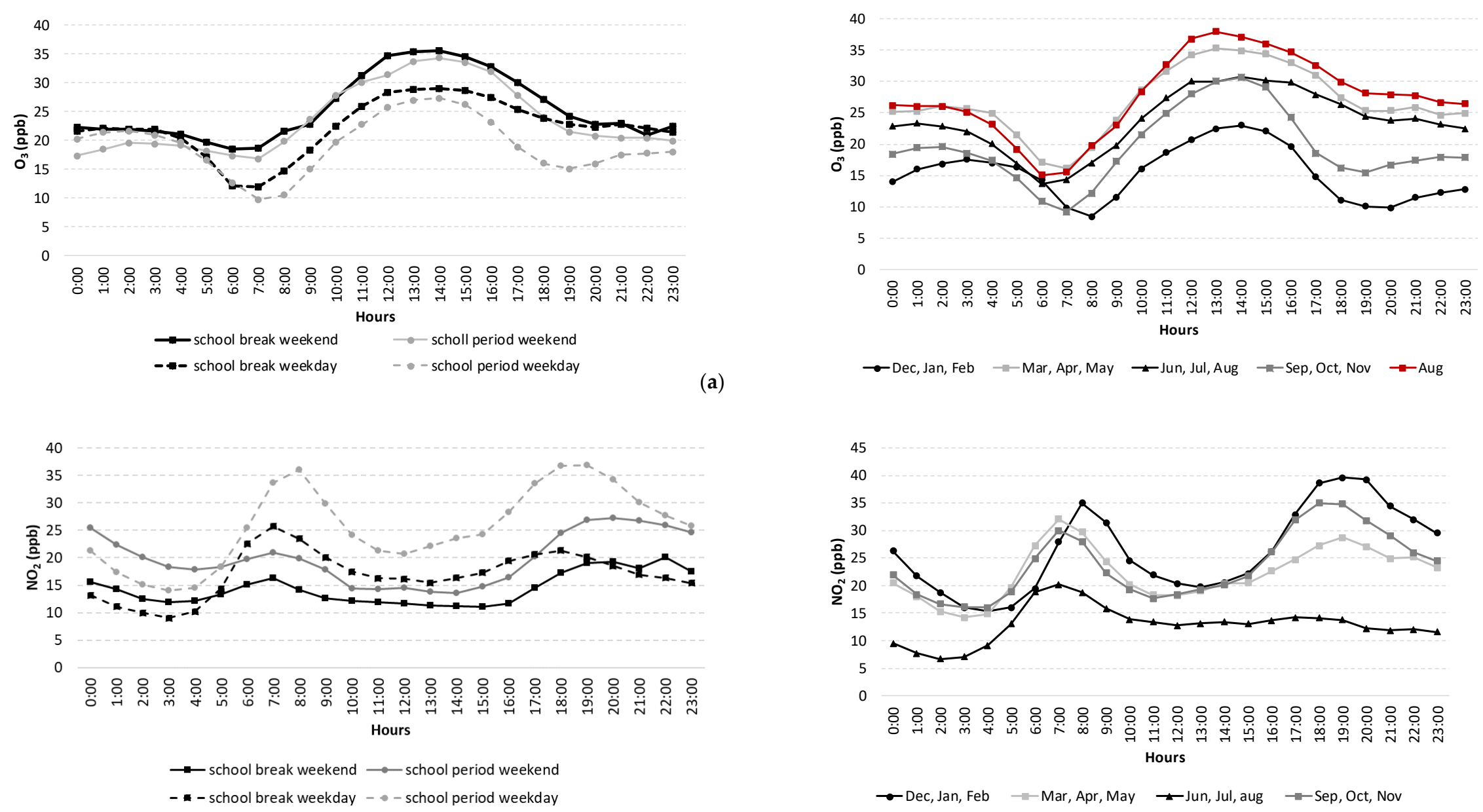

(c)

(d)

Figure 6. (a): Ground-level ozone on an average day for each school season (weekday and weekend); (b): seasonal ground-level ozone concentration hot spot; (c): ground level $\mathrm{NO}_{2}$ concentration on an average day for each school season (weekday and weekend); (d): seasonal $\mathrm{NO}_{2}$ concentration. 

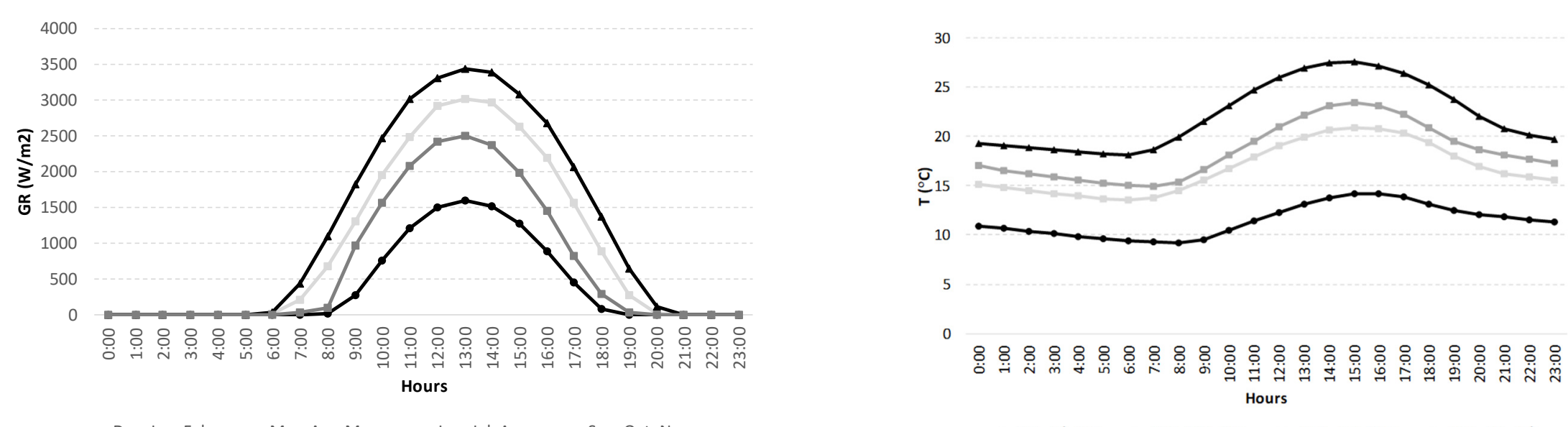

(a)

-Jun, Jul, Aug $\quad=$ Sep, Oct, Nov $\rightarrow$ Mar, Apr, May $\rightarrow$ Dec, Jan, Feb

0.30

(b)

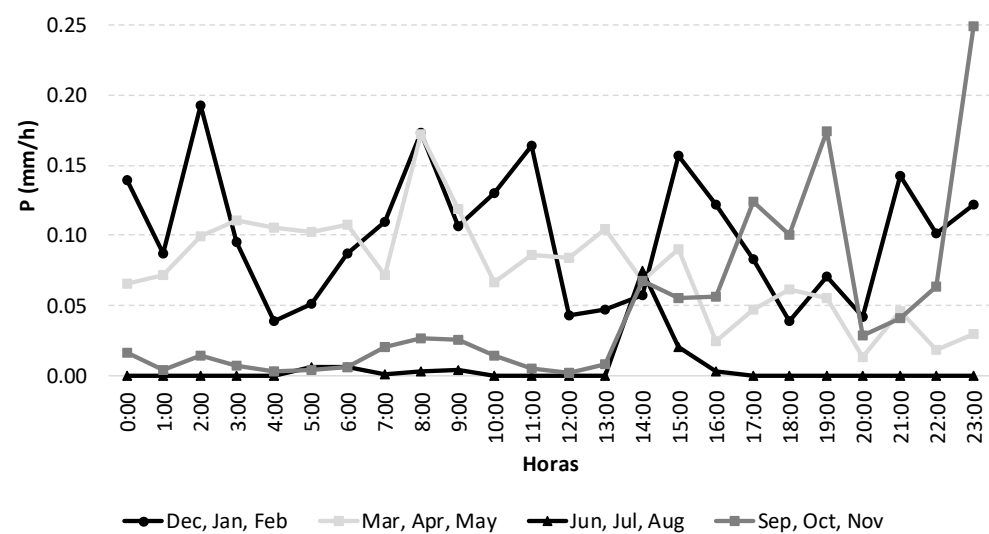

(c)

Figure 7. (a) Seasonal global radiation; (b) seasonal average temperature; (c) seasonal precipitation. 


\subsection{Ground Level Ozone, Global Radiation, and Nox Precursors}

Daytime ozone formation, according to Reaction 1, is proved to be GR dependent. $\mathrm{NO}_{\mathbf{x}}$ precursors prove also to be highly influential to a lesser extent. Regarding the climate variable precipitation, "rain", there is no relationship between ozone and this variable as seen in Figure 8. Both effects can be seen in Figure 9.

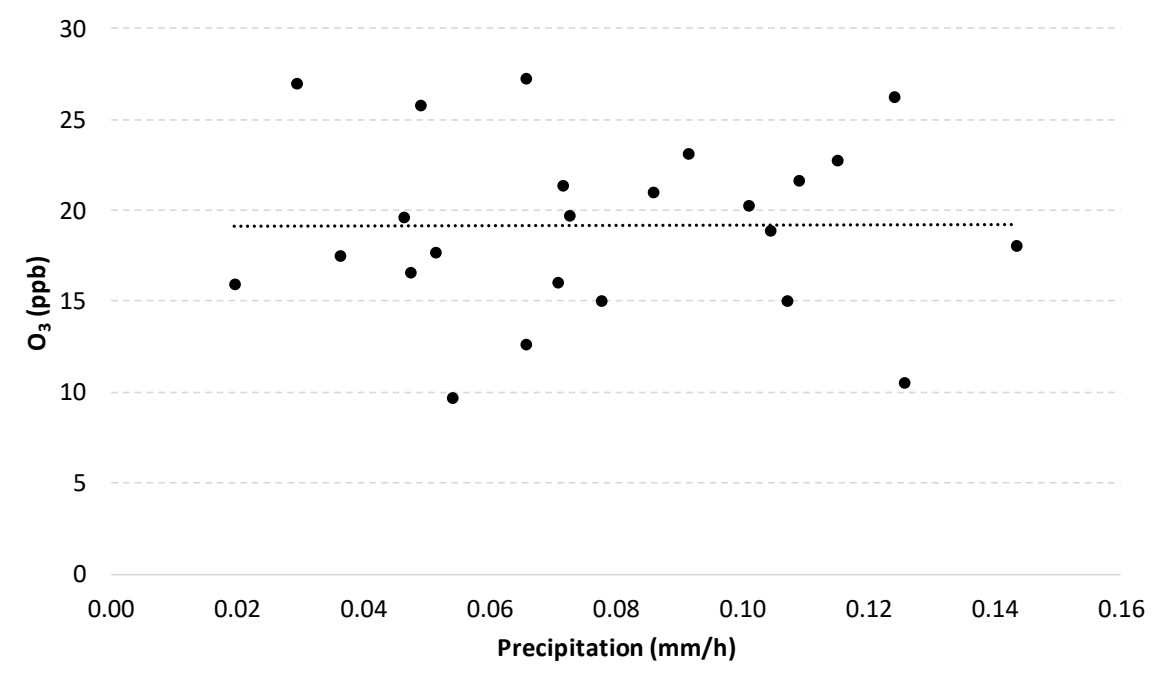

Figure 8. Ozone and precipitation average weekday school period.

Using the average day of the period: peak concentration at weekend minus peak concentration at weekday, divided by peak concentration at weekday, the rise in the 2017 school break period was $20 \%$ and the drop in $\mathrm{NO}_{2}$ was $37 \%$. In the school period, the rise in $\mathrm{O}_{3}$ was $26 \%$ and the drop in $\mathrm{NO}_{2}$ was $26 \%$. Regarding the quantification of the nighttime decrease, we measured it by using the average day of the year 2017 and by calculating the percentage difference in the daily peak, minus the nighttime lowest value and divided by the day peak. Using this method, we observed a drop in $\mathrm{O}_{3}$ of $58 \%$ and $\mathrm{NO}_{2}$ drop of $54 \%$. Similar behavior was seen in school versus holiday periods.

Pertaining to the quantification of the weekend increase and to compare with other studies, we must use the same metric. Each study uses different ways to quantify the weekend effect. The magnitude of the weekend effect in the Arizona 2001-2003 summer period was between 6\% to 17\%, depending on the station location, using the percentage difference in the mean on Sundays minus the mean on Wednesdays, divided by the mean on Wednesdays. Using this method, in our summer period, the weekend metric resulted in $28 \%$ increase.

In the city of Pune, India, for the period summer 2001-2005, the weekend effect was $60 \%$ using the difference between peak concentration in weekend and peak concentration in weekday. Using this method in our summer period, the weekend metric resulted in $35 \%$. So, it seems our weekend effect would be analogous to Arizona.

Two European cities, Belgrade [26] (urban area in the autumnal period of 2005) and Barcelona [25] (13-16 August 2020) revealed a weekend effect of 56\% and 54\%, respectively. Using the metric of average weekend concentration minus average weekday concentration, divided by average weekday concentration, gives us a weekend effect increase of $33 \%$. 

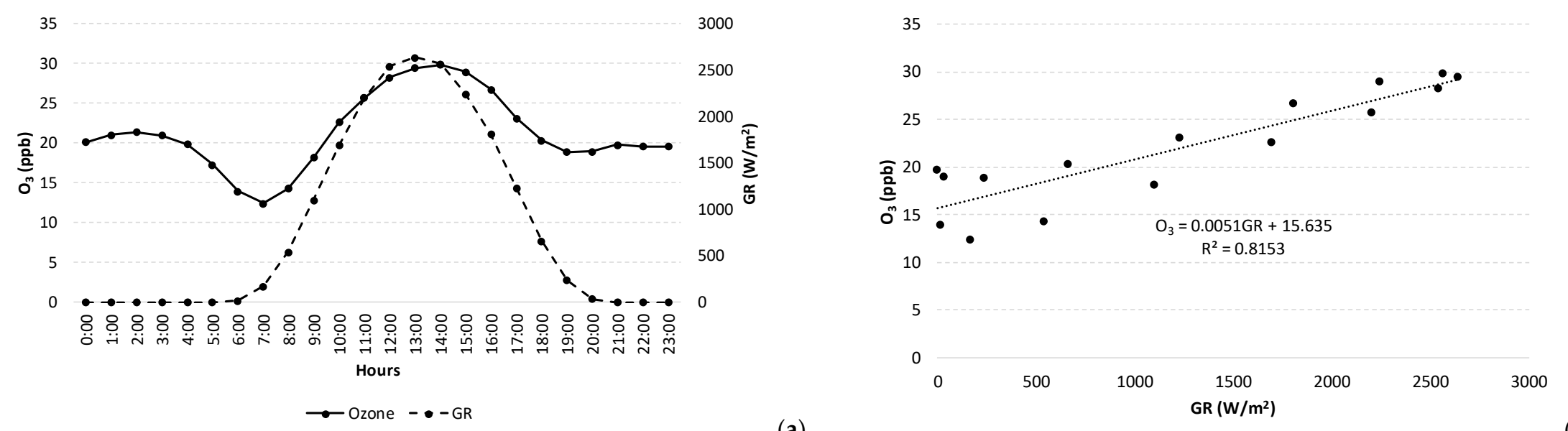

(a)
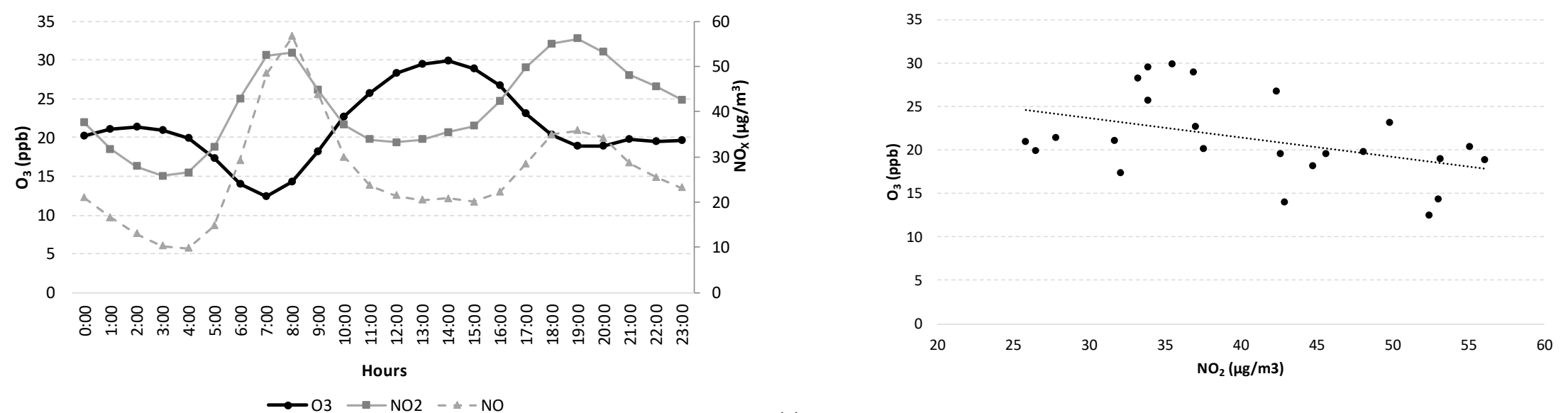

(c)

(d)

Figure 9. Tropospheric ozone correlations (a): average day of 2017 ozone with GR; (b): average daytime of 2017 ozone with GR; (c): school period weekday ozone with NOx and (d): average day of 2017 ozone with $\mathrm{NO}_{2}$. 


\section{Discussion}

We compared our results with other reviewed studies, as presented in Table 2, the values observed in 2017 in Lisbon are similar to other cities (Arizona, India, China, Barcelona, Belgrade), but seem lower than Rio de Janeiro, Cairo, and Mexico City, and much lower than previous Los Angeles smog episodes. Summer is consistently the hot spot season for $\mathrm{O}_{3}$. The reported weekend effect is observed in all cities, but the magnitude is calculated in different manners which makes the comparison between the studies very difficult. In our study, we suggest a method to quantify the magnitude of $\mathrm{O}_{3}$ rise and $\mathrm{NO}_{2}$ decrease in the weekend and $\mathrm{O}_{3}$ and $\mathrm{NO}_{2}$ drops at night. It is necessary to harmonize these metrics globally if the extent of the weekend and the nighttime effect is to be historically monitored and compared worldwide.

A broader yearly database, 2004 to 2021, is being evaluated to also monitor peak ozone levels, historical evolution and somehow correlate the evolution with political measures to improve mobility in Lisbon [32], such as $\mathrm{NO}_{\mathrm{x}}$ reduction measures by selling vehicles equipped with selective catalytic reduction (this will work on the decrease of $\mathrm{NO}_{x}$ level, but could have a counterintuitive result by decreasing ozone titration); since 2018 there has been a boom in electric bike-sharing systems and shared scooters; since 2019, a substantial decrease in public bus pass fee has taken place, from 100 euros to only 40 euros a month, this measure was simultaneous with the rollout of more natural gas buses and e-buses.

\section{Conclusions}

This research seeks to observe trends in tropospheric ozone and its precursors. As a first approach, the year 2017 was analyzed. We found that:

- $\mathrm{O}_{3}$ is highly correlated with global radiation and temperature, the peak being in summer, more specifically August, weekend and school break period (71 ppb);

- $\mathrm{O}_{3}$ has an opposite behavior compared to $\mathrm{NO}_{\mathrm{x}}$ levels, higher $\mathrm{O}_{3}$ means lower $\mathrm{NO}_{2}$;

- $\mathrm{O}_{3}$ has no correlation with precipitation;

- Lisbon Entrecampos roundabout levels are like other cities in this last decade, such as theUS, India, China, Barcelona, Belgrade, but seem lower than Rio de Janeiro, Cairo, and Mexico City;

- Titration reaction (ozone destruction) seems to be the strongest explanation for the weekend effect; $\mathrm{NO}_{2}$ levels decrease $37 \%$ and $\mathrm{O}_{3}$ increases $20 \%$ in school break period; metric measured by peak concentration at weekend minus peak concentration at weekday divided by peak concentration at weekday; In-School period, during the weekend, the rise in $\mathrm{O}_{3}$ is even higher, approximately $26 \%$;

- LCS for $\mathrm{NO}_{2}$ should measure below $50 \mathrm{ppb}$, the SGX Sensortech (Neuchâtel - Switzerland) MICS-4514 was used, but should be avoided in cities in summer season as most of the data falls outside of its measuring range;

- $\quad$ LCS for $\mathrm{O}_{3}$ should measure below $70 \mathrm{ppb}$ with an uncertainty of $25 \%-30 \%$ (DQO), so the use of the Zhengzhou Winsen Electronics MQ-131 is only adequate in a limited amount of cases (in our case in $60 \%$ of the data);

- LCS have many limitations, but calibration in real conditions proved to be useful to evaluate sensor performance;

- LCS from the same family may behave differently, so it is recommended the duplication of sensors on the prototype equipment as well as having one $\mathrm{T} / \mathrm{RH}$ sensor outside and inside the equipment.

Supplementary Materials: The 2017 historical data used in the analysis is available at http://www.mdpi.com/ 1996-1073/13/7/1562/s1.

Author Contributions: D.N. completed his master thesis by evaluating data for the year 2017; T.A. completed his master thesis by building and testing a low-cost sensor case; A.R.S. helped with sensor mounting and testing, writing and organized the supplementary materials; C.S. mentored the students, established the contacts with IPMA and CCDR-LVT and wrote the majority of the manuscript. All authors have read and agreed to the published version of the manuscript. 
Funding: The authors would like to acknowledge the financial support FCT through project UIDB/50019/2020 - IDL

Acknowledgments: IPMA for meteorological data provision; CCDR LVT for permission to install the low-cost equipment on the AQS rooftop and to provide the $\mathrm{O}_{3}$ and $\mathrm{NO}_{2}$ data for the measurement campaign. The authors would like to acknowledge the financial support FCT through project UIDB/50019/2020 - IDL.

Conflicts of Interest: The authors declare no conflict of interest.

\section{References}

1. McKee, D. Tropospheric ozone: Human health and agricultural impacts. Choice Rev. Online 1995. [CrossRef]

2. Berman, J.D. Health benefits from large-scale ozone reduction in the United States. Environ. Health Perspect. 2012. [CrossRef]

3. Jalaludin, B.B.; O'Toole, B.I.; Leeder, S.R. Acute effects of urban ambient air pollution on respiratory symptoms, asthma medication use, and doctor visits for asthma in a cohort of Australian children. Environ. Res. 2004. [CrossRef]

4. IPPC. Climate Change. In Contribution of Working Group III to the Fifth Assessment Report of the Intergovernmental Panel on Climate Change; Cambridge University Press: Cambridge, UK, 2014.

5. Seguel, R.J.; Morales, S.R.G.E.; Leiva, G.M.A. Ozone weekend effect in Santiago, Chile. Environ. Pollut. 2012. [CrossRef]

6. Koo, B. Impact of meteorology and anthropogenic emissions on the local and regional ozone weekend effect in Midwestern US. Atmos. Environ. 2012. [CrossRef]

7. The Ozone Weekend Effect in California; Draft Staff Report and Technical Support Document. Available online: https://ww3.arb.ca.gov/research/weekendeffect/arb-final/wee_sr_ch0.pdf (accessed on 15 March 2020).

8. Parrish, D.D.; Xu, J.; Croes, B.; Shao, M. Air quality improvement in Los Angeles—perspectives for developing cities. Front. Environ. Sci. Eng. 2016. [CrossRef]

9. SilvaJúnior, R.S.; Da Oliveira, M.G.L.d.; Andrade, M.d.F. Weekend/weekday differences in concentrations of ozone, nox, and non-methane hydrocarbon in the metropolitan area of São Paulo. Rev. Bras. Meteorol. 2009. [CrossRef]

10. Kumar, P. The rise of low-cost sensing for managing air pollution in cities. Environ. Int. 2015. [CrossRef]

11. Castell, N. Can commercial low-cost sensor platforms contribute to air quality monitoring and exposure estimates? Environ. Int. 2017. [CrossRef]

12. Soares, A.; Catita, C.; Silva, C. Exploratory research of $\mathrm{CO} 2$, noise and metabolic energy expenditure in Lisbon commuting. Energies 2020, 13, 861. [CrossRef]

13. Hester, R.E.; Harrison, R.M. Air Quality in Urban Enviroznments; Royal Society of Chemistry: London, UK, 2009.

14. Blacet, F.E. Photochemistry in the Lower Atmosphere. Ind. Eng. Chem. 1952. [CrossRef]

15. Atkinson-Palombo, C.M.; Miller, J.A.; Balling, R.C. Quantifying the ozone 'weekend effect' at various locations in Phoenix, Arizona. Atmos. Environ. 2006. [CrossRef]

16. Fujita, E.M. Diurnal and weekday variations in the source contributions of ozone precursors in california's south coast air basin. J. Air Waste Manag. Assoc. 2003. [CrossRef] [PubMed]

17. Parra, R.; Franco, E. Identifying the Ozone Weekend Effect in the air quality of the northern Andean region of Ecuador. Air Pollut. XXIV 2016. [CrossRef]

18. García-Reynoso, A. Ozone weekend effect analysis in México City. Atmosfera 2009, 22, 281-297.

19. Martins, E.M.; Nunesa, A.C.L.; Corrêa, S.M. Understanding ozone concentrations during weekdays and weekends in the urban area of the city of rio de janeiro. J. Braz. Chem. Soc. 2015. [CrossRef]

20. Debaje, S.B.; Kakade, A.D. Weekend Ozone Effect over Rural and Urban Site in India. Aerosol Air Qual. Res. 2006. [CrossRef]

21. Tang, W.Y. Study of ozone 'weekend effect' in Shanghai. Sci. China Ser. D Earth Sci. 2008. [CrossRef]

22. Zou, Y. The weekday/weekend ozone differences induced by the emissions change during summer and autumn in Guangzhou, China. Atmos. Environ. 2019. [CrossRef]

23. Pires, J.C.M. Ozone Weekend Effect Analysis in Three European Urban Areas. Clean Soil Air Water 2012. [CrossRef] 
24. Khoder, M.I. Diurnal, seasonal and weekdays-weekends variations of ground level ozone concentrations in an urban area in greater Cairo. Environ. Monit. Assess. 2009. [CrossRef]

25. Jiménez, P.; Parra, R.; Gassó, S.; Baldasano, J.M. Modeling the ozone weekend effect in very complex terrains: A case study in the Northeastern Iberian Peninsula. Atmos. Environ. 2005, 39, 429-444. [CrossRef]

26. Marković, D.M.; Marković, D.A.; Jovanović, A.; Lazić, L.; Mijić, Z. Determination of O3, NO2, SO2, CO and PM10 measured in Belgrade urban area. Environ. Monit. Assess. 2008, 145, 349-359. [CrossRef] [PubMed]

27. Spinelle, L.; Gerboles, M.; Villani, M.G.; Aleixandre, M.; Bonavitacola, F. Field calibration of a cluster of low-cost available sensors for air quality monitoring. Part A: Ozone and nitrogen dioxide. Sens. Actuators $B$ Chem. 2015. [CrossRef]

28. Peterson, P.J.D. Practical use of metal oxide semiconductor gas sensors for measuring nitrogen dioxide and ozone in urban environments. Sensors 2017, 17, 1653. [CrossRef] [PubMed]

29. Barcelo-Ordinas, J.M.; Doudou, M.; Garcia-Vidal, J.; Badache, N. Self-calibration methods for uncontrolled environments in sensor networks: A reference survey. Ad Hoc Networks 2019. [CrossRef]

30. Hagler, G.S.W.; Williams, R.; Papapostolou, V.; Polidori, A. Air Quality Sensors and Data Adjustment Algorithms: When Is It No Longer a Measurement? Environ. Sci. Technol. 2018. [CrossRef]

31. QualAr. Air Quality Monitoring Network of Portugal. Available online: https://qualar.apambiente.pt/ (accessed on 15 March 2020).

32. Soares, A.; Carla, S. Impact of sustainable mobility measures in reducing ground level ozone. In Proceedings of the ICUR 2020-2nd International Conference on Urban Risks-Centre on Urban Risks (CERU), Lisbon, Portugal, 25-27 June 2020.

(C) 2020 by the authors. Licensee MDPI, Basel, Switzerland. This article is an open access article distributed under the terms and conditions of the Creative Commons Attribution (CC BY) license (http://creativecommons.org/licenses/by/4.0/). 